\title{
Governance of Co-operative Organizations: A Social Exchange Perspective
}

\author{
Iiro Jussila (Corresponding author) \\ Department of Management and International Business \\ School of Business, Lappeenranta University of Technology \\ P.O. Box 20 FIN-58351, Finland \\ E-mail: iiro.jussila@lut.fi \\ Sanjay Goel \\ Department of Management Studies \\ Labovitz School of Business and Economics \\ University Of Minnesota, Duluth \\ 412 Library Drive, Duluth MN 55812-3029, USA \\ E-mail:sgoel@d.umn.edu \\ Pasi Tuominen \\ Department of Management and International Business \\ School of Business, Lappeenranta University of Technology \\ P.O. Box 20 FIN-58351, Finland \\ E-mail: pasi.tuominen@lut.fi
}

Received: March 31, 2012

Accepted: April 25, 2012

Online Published: June 5, 2012

doi:10.5430/bmr.v1n2p14

URL: http://dx.doi.org/10.5430/bmr.v1n2p14

Ranjan Karri and Juha-Matti Saksa provided valuable comments on an earlier version of this paper. The authors also thank the research assistance provided by the Finnish Cultural Foundation, which facilitated co-operation between the authors.

\begin{abstract}
This paper introduces social exchange theory as a promising framework for analyzing co-operative organizations and a helpful tool for deepening our understanding of their governance. We suggest that social exchange is one of the foundational elements of co-operation among member-owners as it provides the impetus for initiating organized co-operative activity among those actors, which is then facilitated with formal co-operative arrangements. Further, we suggest that there is a connection between key constructs of social exchange, e.g. members' motivations for exchange, the resources they exchange, and the forms the exchange takes, and the sustainability and success of co-operative exchange relationships. Overall, the ideas set forth in this paper may offer a number of avenues for future research, especially in the area of formation, governance, and management of co-operative organizations.
\end{abstract}

Keywords: Social exchange, Co-operation, Co-operative, Governance

\section{Introduction}

For decades, corporate governance literature has implicitly assumed that only publicly traded firms are a worthy subject of analysis (Blair, 1995). While this assumption may still hold today in proportional terms, a gradual change is also visible in governance literature. Researchers are realizing that without acknowledging the variety of organizational forms in which firms exist, business and management research would involve only a fraction of all 
economic activity, even in the most advances market societies (Turnbull, 1997). Related to this realization, researchers are paying increasing attention to the identity of owners. For example, focus on the role of family identity both shaping as well as being shaped by a particular business (Rantanen and Jussila, 2011) has led to emergence of family business as a field of its own with researchers and educational centres all over the globe specializing in developing the intellectual underpinnings that accommodate a more varied purpose of business and a wider set of owners (Sharma, Hoy, Astrachan, \& Koiranen, 2007).

One organizational form that is receiving increasing attention is the co-operative form of organization. For a long time this traditional form of organization was neglected by researchers despite its great economic and social importance (Normark, 1996; Hansmann, 1996). According to the International Co-operative Alliance (2012a) the reach of this organization form is visible in the at least one billion members in co-operative organizations world wide. The impact is also seen in the fact that these organizations provide more jobs than all multinational corporations put together, and in the fact that the largest 300 co-operatives alone are responsible for an aggregate turnover of over one trillion USD annually (International Co-operative Alliance, 2012b). While co-operatives have a long way to make it into the mainstream of business management research, scholars from these areas have shown interest in the co-operative model as a way to organize work (Estrin, Jones, \& Svejnar, 1987) and the production of goods and services in a variety of sectors such as agriculture (Saksa, Jussila, \& Tuominen, 2007), fair trade (Fridell, 2009), banking (Jones \& Kalmi, 2009), credit (Bontems \& Fulton, 2009), retail (Tuominen, Jussila, \& Rantanen, 2010), housing (Sousa \& Quarter, 2005), water supply (Takala, Arvonen, Katko, Pietilä, \& Åkerman, 2011), electricity (Wilson, Plummer, Fischlein, Smith, 2008), and other local services often considered to fall into the public domain (Lang \& Roessl, 2011).

While research on co-operatives can be seen in general about study of a particular and distinct organizational form, in this paper we focus specifically on co-operative governance to provide additional rigour to the intellectual framework on the topic. More precisely, we use social exchange theory (e.g., Emerson, 1972; Blau, 1964; Thibault \& Kelley, 1959; Homans, 1958) as a lens to analyze literature on this subject. Our choice of this lens is underpinned by the fact that social exchange has emerged as among the most influential conceptual paradigms for understanding human behaviour in general and organizational behaviour in particular (e.g., Flynn, 2005; Cropanzano \& Mitchell, 2005). As will be shown, social exchange theory provides a good conceptual foundation in conducting a more detailed analysis of co-operative governance and, more importantly, arriving at propositions on the antecedents of sustainable and successful co-operation.

In the following we will first provide the reader with a brief description of the social exchange constructs of value to the study of co-operatives. Next, co-operative governance is analyzed using these construct. Each section ends with propositions on the connection of particular exchange construct with sustainable and successful co-operative governance. In conclusion, the importance of the social exchange framework for the study of co-operation is stressed. We also discuss some limitations and a few avenues for future research.

\section{Co-operatives as seen through the lens of social exchange theory}

Social exchange theory (SET) has its roots in multiple disciplines, such as anthropology (e.g., Sahlins, 1972; Firth, 1967), social psychology (e.g., Gouldner, 1960; Thibault \& Kelley, 1959; Homans, 1958), and sociology (e.g., Blau, 1964; Emerson, 1972). The rich set of concepts composing the theory provide us with understanding on the motivations and outcome expectations for exchange, the resources of exchange and the extent to which the identity of exchange partners is important, and the forms through which exchange is organized.

What is evident from SET perspective is that individuals have diverse motives for engaging in social exchange (e.g., Cropanzano \& Mitchell, 2005; Ekeh, 1974). There motivations may vary from individualistic to collectivistic and, thereby, be associated with the expectations of outcomes of individual or collective value (Flynn, 2005; Molm, 1994; Ekeh, 1974; Lévi-Strauss, 1969). Value is most generally calculated as the difference between the reward and the cost of exchange. Of individual value would be for example those outcomes that can be apportioned to and are consumable by individuals. Of collective value would be outcomes that benefit the entire collective and as such cannot be divided in shares (i.e. cannot be apportioned to individuals). The outcome expectations, in turn, play a key role in individual's decisions to enter or leave an exchange relationship (Flynn, 2005). Those, who seek individual gain will not enter or remain if they expect only collective outcomes from the exchange. On the other hand, those, who seek collective rewards, will not be motivated by expectations of merely individual outcomes from the exchange.

In addition to motivations and outcome expectations, SET has also sharpened the definition of resources for exchange over the years (Cropanzano \& Mitchell, 2005). An influential work in this area was pioneered by Foa and 
Foa's (1974; 1980) work on resource theory. They present different types of resources in exchange organized in a two dimensional matrix - the resource's particularism (vs. universalism), and its concreteness (vs. abstractness). Particularism refers to the idea that the resource's worth varies based on its source (i.e., the extent to which it is important who the exchange partner is). For instance, money is relatively low in particularism - its monetary value is constant regardless of who provides it. Love, on the other hand, is highly particularistic, and its importance depends on its source. Concreteness of a resource refers to its tangibility. Most services and goods are at least somewhat concrete. Less concrete resources provide symbolic benefit that goes beyond objective worth. Foa and Foa's (1974; 1980) works also classify resources in another way - whether they lead to economic and socioemotional outcomes. Economic outcomes are those that address financial (and physical) needs and tend to be tangible. Socioemotional outcomes are those that address one's social and esteem needs (and are often symbolic and particularistic) - for instance by reinforcing that a person is valued and/or treated with dignity (Shore, Tetrick, \& Barksdale, 2001).

According to SET, the motivations and outcome expectations have an effect on the form of exchange preferred by the exchange partners - the explicit or implicit expectations and norms (guiding the resource exchange) in a relationship. Flynn (2005) divides these forms based on their level of direct-indirect reciprocation and the discussion of exchange terms. Negotiated exchange (involving open and explicit bargaining of the terms of exchange) is considered to emerge when actors' decisions are based (nearly) exclusively on self-interest and there is high risk of opportunism in a relationship (Cropanzano \& Mitchell, 2005). The time horizon of reciprocation is relatively short. Generalized exchange is about indirect giving and receiving of benefits that occur among three or more interdependent exchange partners with a much longer time horizon of reciprocation. It refers to repayment of a kind, but not necessarily by the original recipient or the giver (Das \& Teng, 2002; Molm, 1994). In this form of exchange there is a higher degree of trust among group members and a collectivistic orientation, since actors are assumed to put (at least on the short-term) collective interests over personal interests (Flynn, 2005). Here the role of social exchange is highlighted, as one of the basic ideas of SET is that relationships have the potential to evolve over time into trusting, loyal, and mutual commitments (e.g., Cropanzano \& Mitchell, 2005).

In the following sections we will analyze co-operative governance literature using a number of social exchange constructs - asking what are members' exchange interests and expectations for the outcomes of exchange, what resources are exchanged and to what extent is the identity of exchange partners important, and what are the forms of exchange? In connection to answering these questions we pay particular attention to how the social exchange constructs can be seen as connected to sustainable and successful co-operation. While the answers to these questions are not all inclusive, we believe that the material we use serves to illustrate some of the key aspects of co-operative governance and particularly the role of social exchange in it and, thereby, the value of social exchange constructs in the study on the topic.

\subsection{Economic exchange interest and expectation of economic gains}

In literature on consumer co-operation (Tuominen, Jussila, \& Kojonen, 2009), it has been established that in many markets consumers exchange a co-operative contribution (a specific sum of money, such as $€ 100$ ) for ownership rights - essentially the right to gain benefits (e.g., lower price, patronage refunds) through the use of services their co-operative provides. In a worker-owned co-operative, the economic incentive for membership is the expectancy of higher wages (including the right to the surplus according to their work activity) one can get through working in a firm owned by the workers themselves instead of an outside investor (Johnson, 2006; Bataille-Chedotel \& Huntzinger, 2004). In a farmers' (marketing) co-operative, a farmer's membership in the co-operative is motivated by a higher price for inputs though supplying the co-operative as opposed to contracting with an investor-owned processor (Hendrikse \& Veerman, 2001). According to Tuominen et al., (2009), members of consumer co-operatives also steer their co-operative through buying the goods and services that they consider as delivering the most value. In other words, the decision to enter a co-operative exchange relationship and maintain that relationship is based on the expectation of economic gains.

While individualistic orientation to exchange may sometimes be seen as the primary motivation, it is not all that there is to co-operation (Birchall \& Simmons, 2004). For example consumers can only get their benefits by pooling their resources in their local or regional co-operatives (Jussila, Saksa, \& Tienari, 2007) and by leveraging these benefits via networking with other co-operatives for additional economies of scale (Kurimoto, 2008). The idea of pooling also applies to worker co-operatives in which it is the workers' joint labour and democratic control that together lead to productivity gains (e.g., through lower bureaucracy costs), which are the source of additional pay (Johnson, 2006). In a farmers' co-operative, the pooling of resources in the collective organization seems crucial as modern farming practices call for diversification and specialization (Hendrikse, Smit, \& de al Vieter, 2007), which 
require significant investments in different processing technologies. What clearly speaks in favour of collectivistic motivations is that all the financial resources accumulated that go beyond the total sum of members' co-operative contributions are the members' (indivisible) common property to which no single individual can claim sole ownership rights (Bataille-Chedotel \& Huntzinger, 2004; Nilsson, 2001). It is this collective resource pool that is a source of the co-operative's effectiveness in its environment and provides it with the ability to compete.

Successful and sustainable co-operative organizations therefore are likely to exhibit a strong foundation of both individual and collective economic interest as well as outcomes. The individual's economic interest, which can only be realized if the individual contributes tangibly to the co-operative effort, keeps the economic cost of organization low, and provides it a competitive raison d'etre relative to other organizational forms. Collective economic interest provides the scale to make economic value added feasible. Expectations of individual outcomes provide individuals a metric to evaluate their effort relative to individual benefits. Expectations of collective economic outcomes provide individuals a metric to evaluate the adequacy and effectiveness of collective co-operative effort. An imbalance in individual and collective interests and expectations may result in the failure of co-operative action and organization, as individual efforts may fall short of what is required for sustainable co-operative action.

Thus, we propose:

Proposition 1a: Sustainable and successful co-operative exchange relationships are based on a balance of individual and collective economic interest.

Proposition 1b: Sustainable and successful co-operative exchange relationships are based on an expectation of balance between both individual and collective economic outcomes.

\subsection{Social exchange interest and the expectation of socio-emotional outcomes}

While economic exchange typically dominates discussions around business firms, we assert that in co-operatives, it is the voluntary and informal social exchanges that provide the best impetus for initiating organized co-operative activity among members - as opposed to them being, for example, formal and government led (top-down) projects which 'members' feel no belongingness to (Birchall \& Simmons, 2010). In this context, commonality of interests, benefits from co-operation, and a desire to establish a social exchange relationship may be natural triggers to initiate co-operation and co-operative organization (Blau, 1964). In particular, initial exchanges may help develop an understanding of the degree of interdependence of parties on each other, as well as the degree of jointness in the exchange task (Lawler, 2001), which may lead to a shared understanding, conceptualization of, and commitment to, a co-operative organization (Birchall \& Simmons, 2004).

What speaks to the importance of social exchange theory in explaining successful co-operative governance is that it helps understand the importance of reciprocal exchange that takes place under conditions of incomplete contracts (Das \& Teng, 2001). For example in farmers' co-operation contracts are incomplete "as the complexity of the real world makes it too costly to describe all relevant contingencies regarding the exchange in a contract" (Hendrikse \& Veerman, 2001: 54). In other words, the farmers must deliver inputs to their co-operative without the knowledge of the final price for their product. To avoid risks the farmers are expected to settle for a lower price first and after the accounting period collectively decide about the use of surplus. As the complexity of the business and technical environment has grown (following a change of markets from sellers' to buyers' markets), creating demands for diversification of product portfolios (Hendrikse, et al., 2007), the ex post negotiation has become even more important. Democratic (one-person-one-vote) determination of the broad uses to which organizational resources (collective property) will be deployed (i.e., governance; cf. Daily, Dalton, \& Cannella, 2003) are made in other co-operatives too (e.g., Tuominen et al., 2009). Here it is important that the co-operators expect their voice to be heard (i.e., they will have a say) and trust those they are interdependent with. As the work of Jussila et al. (2007) shows, the decision-making process often includes the resolution of conflicts among the myriad of participants to co-operations - conflicts that may in particular arise in the context of incomplete contracts. These conflicts may get exacerbated if members may have differing expectations from each other due to a lack of shared understanding of norms based on reciprocal exchanges, or an inordinate, imbalanced deficit in expectations as a result of imbalanced exchanges over a period of time. Governance in successful co-operatives could then be conceptualized as managing these expectations and reducing imbalances to accrue over time.

The role of the social and socio-emotional aspects of social exchange in successful governance of co-operatives is further highlighted by the fact that managerial action in co-operatives is not constraint by stock market forces (Cornforth, 2004; Spear, 2004). Boards, for example, have less institutionalized measures to evaluate co-operative performance and exerting influence may be more difficult than in investor-owned firms (Tuominen et al., 2009; 
Cornforth, 2004). Therefore, they may rely on relational governance measures to monitor and mentor the co-operative managers. Tuominen et al. (2009) also point out that where exit from the organization is impossible (where no alternatives exist) or where strong affective commitment leads to the decision to stay, the members are likely to use their voice more effectively, and engage in meaningful social exchanges in addition to the economic, that materializes in improvements of operations, leading to more efficient and purposeful deployment of the organization's resources. Thereby, we envision that frequent and high quality social exchange among members, representatives and the management is a necessity for effective governance of a co-operative. This view is further emphasized as one considers the governing actors' contributing role (imbued with stewardship perspective), boundary spanning role (representing the resource dependence perspective), or their role as representatives of broader social interest (representing the stakeholder perspective) and the informal negotiation of these roles among members (Jussila, et al., 2007; Cornforth, 2004; Donaldson, 2003).

Research on worker co-operation (Johnson, 2006) suggests that members' active participation in social exchange (e.g., the negotiation of alternative renditions of reality) is required for deep, contextually situated learning that ensures the development of mutual understanding and a discourse of critique. Quite similar ideas have been put forward in retail context as well. For example the work of Viggiani (1999) highlights the role of members' day-to-day social exchange as constituting the core aspects of a democratic grocery store. It is through the participation, debate, learning, and mutual understanding that the members are empowered and true (i.e., well functioning) democracy is realized - as opposed to for example management hegemony that some perspectives on governance predict (Cornforth, 2004), which is sometimes feared as materializing in co-operatives (Kurimoto, 2008; Spear, 2004), and can be expected to materialize in government imposed co-operative projects (Birchall \& Simmons, 2010). In fact, following the democracy principle of co-operation (Nilsson, 1996), "ethically legitimate organizational praxis arises only where it is the outcome of such empowered collective agreement" (Johnson, 2006: 262). According to Lang and Roessl (2011), many established co-operatives fail at gaining such legitimacy due to an ongoing process of 'economization' in which the (social) interests of the members are replaced by economic measures of corporations. The work of Tuominen et al. (2010) suggests that this is likely to take place particularly when there is a lack of knowledge about the purpose of co-operation.

Considering what we have presented above, it seems that there is a need for the initial exchanges to lead to the development of a threshold level of trust and the transformation of "I" to "We" (cf. Birchall \& Simmons, 2004). This is because the formation of a collective identity is to some extent required for co-operative behaviour (Tyler \& Blader, 2001). It seems reasonable to believe that the co-operators will not enter a co-operative exchange relationship in the first place unless they envision formation of a group identity and expect trust and mutual understanding to develop eventually. According to Birchall and Simmons (2004), sense of community, shared values, and shared goals may sometimes be the most powerful motivations for participation in a co-operative exchange relationship. As we envision the expectation of such collective socioemotional outcomes, the work of Lawler and his colleagues, starting with the theory of relational cohesion (Lawler \& Yoon, 1993; 1996; 1998) and extended by the affect theory of social exchange (Lawler, 2001) provides another rich tapestry to weave in the theory of co-operative governance. The focus of the former was on "understanding the development of commitment to exchange relations and, in particular, the effects of repeated exchange among the same actors" (Lawler, 2001). The role of collective identity and relational cohesion is further illustrated by the characterization of co-operatives as being based on socio-emotional association rather than capital association (e.g., Birchall, 2000; Stryjan, 1994).

Overall, our arguments above are in favour of the notion that sustainable and successful co-operative exchange relationships are predicated on significant socio-emotional stake in, and expectation of benefit from, co-operative action.

Thus, we propose:

Proposition 2a: Sustainable and successful co-operative exchange relationships are based on a balance of individual and collective socio-emotional interest.

Proposition 2b: Sustainable and successful co-operative exchange relationships are based on an expectation of balance between both individual and collective socio-emotional outcomes.

\subsection{Resources exchanged and the identity of exchange partners}

As the above discussion illustrates, a great variety of tangible and intangible resources are mobilized and exchanged in different co-operative exchange relationships with the expectations of a variety of outcomes (cf. Birchall \& Simmons, 2004). Interestingly though, Hendikse et al. (2007) note in comparison to investor-owned firms that, a 
priori, no differences with respect to tangible or intangible resources can be expected, but, in general, co-operatives have less financial resources than corporations as they are more of a social association than that of invested capital.

In consumer co-operatives one can witness exchange of money, time, and effort for goods and services, convenience, price benefits, and patronage refunds (Tuominen et al., 2009). While there is variety in the resource needs of the members, there is sufficient homogeneity in those needs to provide the scale needed to cover the costs of satisfying them. In farmers' co-operatives, exchange involves for example eggs, meat, or milk for price benefits and patronage refunds (Hendrikse \& Veerman, 2001). While there is heterogeneity in the output of the producers, there is sufficient conformity to standard to use those outputs as inputs in the co-operative processing. In worker co-operatives, work contributions (physical resources, skills, intellect, or creative juices) are exchanged to wage-benefits and a fair share of surplus (Johnson, 2006; Bataille-Chedotel \& Huntzinger, 2004). In community co-operatives a variety of actors exchange of donations and voluntary work for common good (Lang \& Roessl, 2011). While there is some extent of fit between the resources exchanged to be combined, there is sufficient variety to allow specialization and distribution of work needed for productivity and the creation of that collective benefit the work is aimed at.

As also shown in the above discussion, successful democracy requires the exchange of a variety of intangible resources leading to both socio-emotional and economic outcomes. Thoughts, information, values, and diverging perspectives are exchanged for learning and the development of mutual understanding (Johnson, 2006;Viggiani, 1999), union of wills (Kaplan de Drimer, 1997), and collective identity (Lang \& Roessl, 2011). Here too, there is a balance between the heterogeneity and homogeneity of resources exchanged and the nature of outcomes expected. As noted above, collective economic outcomes (improved co-operative services) are sometimes also pursued by consumers through the use of voice (Tuominen et al., 2009). With a more specific focus on particular governing bodies such as the board, co-operative literature has identified, for example, the exchange of support for management (advice, trust, skills, and expertise) to better decision quality and the exchange of strategically relevant resources (e.g., knowledge and external contacts) to the success of the co-operative and the region in which it is embedded (Jussila et al., 2007; Cornforth, 2004). In both cases, it is only through diversity in resources exchanged that development can take place in co-operative organizing.

Based on our review, the question of identity of the exchange partners is critical in co-operatives. While in a publicly held firm can be governed by "faceless" investors, in a co-operative it makes great difference who the members are. In the most basic form co-operatives are "facefull" local organizations in which economic and social action is voluntary and connected to peoples' everyday needs, not in politically justified power or in money-based markets (Michelsen, 1994). Depending on the type of the co-operative, consumers (with particular service needs), entrepreneurs (with business specific interests), producers (of particular products), or workers (organized around particular work tasks) are in charge (cf. Holmstrom, 1999). In other words, co-operatives are a union of sufficiently homogenous people with similar needs (Bataille-Chedotel \& Huntzinger, 2004; Kaplan de Drimer, 1997). Identity of members becomes particularly important as the votes in the governance of co-operative are divided following 'one person, one vote' principle, and not in relation to the capital invested, as is the case with limited liability companies (Katz \& Boland, 2002). Further, identity is crucial also in the case of board members boundary spanning and resource roles (Jussila et al., 2007; Cornforth, 2004). This is because it is particular people (not just anyone) who are or can be holders of such network positions or social capital that are of value to the collective.

The importance of particularism is borne out by notions about the importance of locality in the formation and performance of co-operatives (e.g., Lang \& Roessl, 2011; Tuominen, Jussila, \& Saksa, 2006). First, Davis (2001) points out that the services from the co-operative to their members are available entirely due to the associational or community context of a co-operative. In other words, considering the interdependency of the co-operators (in the creation of the co-operative advantage), it is important that the exchange partners inhabit a particular locality or region. Second, in the context of highly dispersed and a stronger separation between ownership (such as in large consumer co-operatives) close and coordinated control can only take place there where members are physically and culturally close to their co-operative (Jussila, et al., 2007; Tuominen et al., 2006; Hansmann, 1999). In other words, as governance is shaped and improved by an inherited framework of collectively held values, norms, and rules, it is important the co-operative exchange partners share a territorial context (Lang \& Roessl, 2011). This makes sense, as work on territoriality of organization (Brown, Lawrence, \& Robinson, 2005) suggests that physical proximity clarifies and simplifies social exchange (e.g., the rules of exchange are unified) and diminishes conflicts of interests (cf. Rosenblatt \& Budd, 1975; Altman \& Haythorn, 1967).

Thus, we propose: 
Proposition 3a: Sustainable and successful co-operative exchange relationships are based on a balanced exchange of both concrete and abstract resources.

Proposition 3b: Sustainable and successful co-operative exchange relationships are based a balanced exchange of resources both low and high on particularism.

\subsection{Forms of exchange}

The above discussion suggests that co-operative exchange relationships are likely to take place under incomplete contracts. However, even though the contracts are not complete, there are still some negotiated and explicit aspects to the exchange relationship. For example farmers do not know the final price for their supply, but there is an explicit price that is used during a particular period (cf. Hendrikse \& Veerman, 2001). Some explicit bargaining (concerning the wages) takes place in worker co-operatives too and in consumer co-operatives the members can simply look at the price tag to see what they have to pay for particular product or service. One can see many of the negotiated elements as following from legislation and regulation in different institutional contexts (cf. Saksa et al., 2007).

Even if there are some negotiated elements to co-operation, the members do not know the behaviours of others in advance or how successful the co-operative will be in carrying out its mission. Depending on the behaviours of others the previously set prices or wages may turn out to have been too high or low leading to ex post collective decisions on the use of surplus or covering the deficit. This speaks to the role of generalized form of exchange in co-operatives (cf. Molm, 1994). In fact, it seems to us that generalized reciprocity is central to co-operation. Co-operatives have been known to prosper in those contexts where there is an emergent mutual interest (e.g., among consumers of insurance services, producers of goat milk) and where the attainment of the collective goals requires a high degree of interdependence among members (Hansmann, 1999). The history of co-operation leads us to believe that the acknowledgement of this interdependence is relevant in terms of continuity of co-operation (Nilsson, 1996). Also successful democracy (in the vein of 'one-member-one-vote') requires a high degree of interdependence among members (e.g., Johnson, 2006; Cornforth, 2004; Nilsson, 2001). The interdependence is embedded in the structure of economic rationality and scale and awareness of benefits of co-operation. Thus, the members' and organization's challenge is to institutionalize this interdependence to create a stable and sustaining organization to reap the benefits that are structurally embedded in co-operation. Therefore, it is easy to see why long-lived co-operatives have typically been characterized with the acknowledgement of interdependence not only among the members, but also between the co-operative and the local surrounding (Tuominen et al., 2006). This is particularly true in community co-operatives in which the membership inhabits a particular territory (co-exists in a specific place and time) and claims to act on behalf of a collective identity (Lang \& Roessl, 2011). It is also noteworthy that the expected time horizon of reciprocation affects the sustainability of the co-operative organization. As Lang and Roessl (2011) point out, it is under the conditions of a mutual belief of the actors that other actors do not want to endanger the relationship and the associated long-term advantages for the sake of short-term advantages that inclination towards opportunistic behaviour is reduced.

Thus, we propose:

Proposition 4a: Sustainable and successful co-operative exchange relationships are based on a balance of negotiated and generalized aspects of exchange.

Proposition 4b: Sustainable and successful co-operative exchange relationships are based on realization of a need for both negotiated and generalized aspects of exchange.

\section{Discussion and conclusion}

In this paper we have focused on the co-operative form of organizing, which seems like a promising field of academic inquiry as one considers the imbalance between the social and economic importance of this organizational form and the amount of academic attention it has received to-date. More specifically, we have taken a social exchange theory perspective on governance of co-operative organizations, shedding light on the motivations for co-operative exchange relationships, the resources exchanged, and the forms of exchange. We have shown that social exchange theory provides additional rigour to the study of co-operative governance.

By analyzing literature on co-operative governance we found that exchange is a fundamental element in co-operation as opposed to, for example, passive capital investment. While a co-operative contribution is required for the right to participate, both individual and collective rewards are in fact created through and dependent on the participation of the members in the co-operative exchange relationship. Considering the antecedents of sustainability and success of this model, our reading of the co-operative literature led us to propose that they include a balance between individual and collective economic interest and, as a related issue, an expectation of balance between individual and collective 
economic outcomes. Without the individual economic interest and expectation of individual economic benefits, the co-operative exchange relationship would lack the individually motivating mechanisms typically associated with it. On the other hand, without a collective economic interest and the expectation of collective economic value, the membership would not be likely to approve the accumulation of collective financial capital and the those investments required to promoting the members interests in the marketplace. Thereby, an imbalance towards individual or collective interest and outcome expectations is likely to jeopardize sustainability and success of co-operation.

Even though social exchange as a theory does include both tangible and intangible resources, we chose to discuss social exchange interest and the expectation of socio-emotional outcomes in a separate section. This not only provides a better outline for the discussion, but also serves to highlight the role of non-economic interests and the expectation of non-economic outcomes in co-operative exchange relationships. In our analysis of co-operative governance literature, we found that both individual socio-emotional value and collective socio-emotional value (e.g., collective identity) are created through and dependent on the social participation of the members in the co-operative exchange relationship. Again, a balance is required in order to sustain the co-operative exchange relationship and to succeed. Without individual socio-emotional interest and the related expectation of personal socio-emotional outcomes (e.g., a feeling of belongingness and empowerment, trust, and affective commitment), the individual member will not be motivated to contribute to the democratic decision-making processes of the co-operative or to even enter the co-operative exchange relationship in the first place. On the other hand, without a collective socio-emotional interest and the expectation of collective socio-emotional value (e.g., collective identity), it is not likely that there will be any belief in the ability of the co-operators to reach collective agreements required to direct the co-operative according to the union of wills rather than for example the co-operative manager's personal interest (which may or may not be in line with those of the co-operators). A harmful imbalance in this context would be that in which members intensively participate in debate with competing perspectives (e.g., in coalitions) thereby developing personal socio-emotional value, but without reaching a sufficient collective agreement, or that in which the mutual understanding is such that does not allow any conflicting perspectives to be presented, thereby undermining the principle of democracy and the potential for high quality decisions in the context of optimum conflict.

A great variety of tangible and intangible resources are mobilized and exchanged in co-operative exchange relationships with the expectations of a variety of tangible and intangible outcomes. As put forward above, exchange between social actors (i.e., members) is highlighted in co-operatives as the source of value instead of the members' capital investments. As far as the nature of resources exchanged is concerned, our analysis suggests that a sustained and successful co-operative exchange relationship is a balanced exchange of both concrete and abstract resources. Even in the seemingly very concrete agricultural business democracy requires the exchange of abstract resources. While the concrete resources are often in the heart of the transformation processes, it is the exchange of wills, values, goals, intellects, and creative juices that provides the rhythm and guidelines to those processes. Further, our analysis suggests that sustainable and successful co-operation requires some extent of standardization (homogeneity) on the one hand and diversity (heterogeneity) on the other hand. The extent to which homogeneity or heterogeneity is required in transformation processes on the one hand and democracy on the other hand seems to be dependent on the co-operative context. Both homogeneity and heterogeneity relate to the question of particularism of the resources exchanged. First, it does make a difference to the sustainability and success of co-operation who the participants are, for example in terms of the fit between their needs and location. Second, particular people possess the specific resources required to make the joint effort a success and to reach high quality collective agreements. Any imbalances are likely to lead to non-optimal performance.

Finally, consistent with the findings related to other social exchange constructs, our analysis on the forms of exchange suggests that both negotiated and generalized aspects are to be found in successful co-operatives. In co-operatives there is some explicit contracting or at least exchange based on, for example, explicit prices. However, the contracts are not complete as the final terms of transaction are subordinate to the outcomes of interdependent exchange both as it related to inputs used in transformation processes and democracy. On the other hand, while some of the exchange is connected to what the members can get right now or at least over a relatively short period of time, there is also longer time horizon reciprocation. What is crucial for sustainable and successful co-operation is that the co-operators acknowledge this duality of form and attempt to maintain a balance. If the exchange relationship leans towards the negotiated form, long-term benefits of co-operation are undermined by opportunistic behaviour. If on the other hand, the exchange relationship leans towards the generalized form, the co-operators may find it difficult to justify to themselves their participation as no clear benefits can be seen on a short-term basis. 


\subsection{Suggestions for future research}

Several areas of future research can be suggested based on the ideas presented in this paper. The significance of social exchange in governance, in both an evolutionary and cross-sectional sense, is likely to vary contextually according to the variation in social exchange rules. For instance, research on social exchange has highlighted the existence of cultural and individual differences in how reciprocity is valued. These differences may affect co-operative governance and co-operative action. For instance, in cultures where reciprocity is valued less, co-operative action may tend to be muted, and negotiated action via appropriate organizations may tend to dominate. Similarly, individuals who tend not to recognize obligations may tend to be weak members of a co-operative organization, and may even tend to weaken the co-operative organization. Thus, the institutional context within which social exchanges take place may influence the reinforcement and reification of co-operative organization. These issues should be pursued further to develop a contextual understanding of co-operative action.

Another approach to studying co-operative organizations is taking a micro perspective and studying the underlying emotions that social exchanges arouse in exchanging individuals. The affect theory of social exchange asserts that exchange outcomes have emotional effects that vary in form and intensity. These variations have second-order effects on the quality of subsequent social exchanges. In addition, since social exchange is essentially a joint activity, and the resulting emotions are attributed to social units (such as relationships or groups), the development of such shared emotions and other shared psychological states have relevance in explaining both the evolution of co-operative governance as well as performance differences among co-operative efforts and their formal governance.

\subsection{Practical implications}

Focusing on a social exchange perspective to understand co-operatives also has some practical implications. In established co-operative organizations, many of the development interventions are imported from corporate organizations. These include business and management expertise, which typically lead to clarification and enforcement of contractual agreements among parties. These interventions may need to be contextualized for co-operative organizations if one recognizes that social exchanges form the foundational basis of successful co-operative organizations. This may lead to interventions that focus on maintaining structures to foster and improve social exchanges, leading to more relational governance and trust based mutual accountability as opposed to contractual governance, which could be more effective in improving the operations, management and governance of co-operative organizations. In addition, the monitoring costs of relational governance based on trust are much lower than those of contractual governance. To see the implications at the grassroots level, where many individuals and organizations aim to promote the co-operative movement, a social exchange perspective suggests that these efforts should centre around harnessing (and even facilitating) social exchanges among the weakest of the members, and let the need for formal structures emerge from the realization of interdependence and the joint production function, rather than overwhelming the felt need for co-operation with complex structures that are alien to members at the outset, and therefore alienate them from the formal co-operative organization. In some countries, where co-operatives are seen as panaceas for empowering the weakest, "co-operatives" are sometimes thrust upon the members, with the assumption that the formal organization will eventually lead to the benefits that members value, which would then legitimize the organization. However, this goes against the co-operative philosophy, since the formal organization's success depends on individual members' efforts, and efforts will not be forthcoming if members do not perceive the organization as legitimate, let alone if the members do not perceive the organization as "theirs." A focus on reducing the "transactions costs" of social exchange among potential members, on the other hand, may serve as a far more effective catalyst in developing stronger and sustainable co-operative organizations in the long run that are accountable to all members.

\subsection{Limitations}

The use of social exchange perspective in the study of co-operative organizations also has a few limitations. It is likely that this perspective glosses over given or inherent differences in power and resources that may exist among potential members due to other institutional norms and structures. In this context, the social exchange may not be balanced - resources that may be "equal" or "near-equal" under some contexts may be symbolically unequal in another context, if the value of the resource is tied to the resource owner and resource giver. Under these conditions, social exchanges will only exacerbate the resource imbalances, as instead of mutual dependence, a unilateral dependence is fostered, creating a feudal relationship rather than a co-operative one - and thus a co-operative organization may not emerge as it is intended to. In addition, because social exchanges need to be "real" and frequent for the norms of exchange to be learned and applied in exchanges, social exchange theory may be stretched to 
explain and predict co-operative organizations that are geographically spread out and may even encompass multiple institutional contexts.

\subsection{Conclusion}

In conclusion, we reassert that social exchange theory has immense potential to deepen our understanding of successful co-operative governance because it takes into account the special features of co-operatives, and provides a sound conceptual foundation for the organization of co-operative effort. In particular, social exchange theory can contribute in developing both a conceptual understanding and practical implications in areas such as evolution and growth of co-operatives and their governance and management, sensitizing members to their role in co-operative operations, rejuvenating failing co-operative movements, and earning legitimacy for the co-operative organizational form from the larger institutional environment, e.g. the government (regulatory and fiscal issues), the consumers, educational institutions, and contractual employees. On a macro level, social exchange theory can help develop better geographical theories of co-operative movements and their regional and local effects. It appears obvious that there is a need for both conceptual and empirical work on the subject. With this paper, we hope to spur future work employing a social exchange perspective in the field of co-operative management in general.

\section{References}

Altman, I., \& Haythorn, W. W. (1967). The ecology of isolated groups. Behavioral Science, 12, 168-182. http://dx.doi.org/10.1002/bs.3830120302

Bataille-Chedotel, F., \& Huntzinger, F. (2004). Faces of Governance of Production Cooperatives: An Exploratory Study of Ten French Cooperatives. Annals of Public and Cooperative Economics, 75, 89-111. http://dx.doi.org/10.1111/j.1467-8292.2004.00244.x

Birchall, J., \& Simmons, R. (2010). The Co-operative Reform Process in Tanzania and Sri Lanka. Annals of Public and Cooperative Economics, 81, 467-500. http://dx.doi.org/10.1111/j.1467-8292.2010.00418.x

Birchall, J., \& Simmons, R. (2004). What motivates members to participate in co-operative and mutual businesses? A Theoretical Model and Some Findings. Annals of Public and Cooperative Economics, 75, 465-495. http://dx.doi.org/10.1111/j.1467-8292.2004.00259.x

Birchall, J. (2000). Some Theoretical and Practical Implications of the Attempted Takeover of a Consumer Co-Operative Society. Annals of Public and Cooperative Economics, 71, 29-54. http://dx.doi.org/10.1111/1467-8292.00132

Blair, M. M. (1995). Ownership and control. Washington DC: The Brookings Institution.

Blau, P. M. (1964). Exchange and power in social life. New York: John Wiley.

Bontems, P., \& Fulton, M. (2009). Organizational structure, redistribution and the endogeneity of cost: Cooperatives, investor-owned firms and the cost of procurement. Journal of Economic Behavior \& Organization, 72, 322-343. http://dx.doi.org/10.1016/j.jebo.2007.05.006

Brown, G., Lawrence, T. B., \& Robinson, S. L. (2005). Territoriality in Organizations. Academy of Management Review, 30, 577-594. http://dx.doi.org/10.5465/AMR.2005.17293710

Cornforth, C. J. (2004). The governance of co-operatives and mutual associations: a paradox perspective. Annals of Public and Co-operative Economics, 75, 11-32. http://dx.doi.org/10.1111/j.1467-8292.2004.00241.x

Cropanzano, R., \& Mitchell, M. S. (2005). Social exchange theory: An interdisciplinary review. Journal of Management, 31, 874-900. http://dx.doi.org/10.1177/0149206305279602

Das, T. K., \& Teng, B-S. (2002). Alliance constellations: a social exchange perspective. Academy of Management Review, 27, 445-456.

Das, T. K., \& Teng, B-S. (2001). Trust, control, and risk in strategic alliances: an integrated framework. Organization Studies, 22, 251-283. http://dx.doi.org/10.1177/0170840601222004

Daily, C. M., Dalton, D. R., Cannella, A. A. Jr. (2003). Corporate Governance: Decades of Dialoque and Data. Academy of Management Review, 28, 371-382.

Davis, P. (2001). The Governance of Co-operatives Under Competitive Conditions: Issues, Processes, and Culture. Gorporate Governance, 1, 28-39. http://dx.doi.org/10.1108/EUM0000000005975

Donaldson, J. (2003). Co-operative Management and Corporate Governance. International Journal of Co-operative Management, 1, 36-42.

Ekeh, P. P. (1974). Social Exchange Theory: The Two Traditions. Cambridge, Mass: Harvard University Press.

Emerson, R. M. (1972). Social Exchange Theory. Annual Review of Sociology, 2, 335-362. http://dx.doi.org/10.1146/annurev.so.02.080176.002003 
Estrin, S., Jones D. C., \& Svejnar, J. (1987). The productivity effects of worker participation: producer cooperatives in Western economies. Journal of Comparative Economics, 11, 40-61. http://dx.doi.org/10.1016/0147-5967(87)90040-0

Firth, R. (1967). Themes in Economic Anthropology, London: Tavistock.

Foa, U. G., \& Foa, E. B. (1974). Societal structures of the mind. Springfield, IL: Charles C. Thomas.

Foa, U. G., \& Foa, E. B. (1980). Resource Theory. Interpersonal Behavior as Exchange. K. J. Gergen, M. S. Greenberg, \& R. H. Willis (Ed.) Social Exchange. Advances in Theory and Research. New York: Plenum Press.

Flynn, F. J. (2005). Identity orientations and forms of social exchange in organizations. Academy of Management Review, 30, 737-750. http://dx.doi.org/10.5465/AMR.2005.18378875

Fridell, G. (2009). The Co-Operative and the Corporation: Competing Visions of the Future of Fair Trade. Journal of Business Ethics, 86, 81-95. http://dx.doi.org/10.1007/s10551-008-9759-3

Gouldner, A. W. (1960). The norm of reciprocity: A preliminary statement. American Sociological Review, 25, 161-178. http://dx.doi.org/10.2307/2092623

Hansmann, H. (1996). The Ownership of Enterprise. London: The Belknap Press of Harvard University Press.

Hansmann, H. (1999). Cooperative Firms in Theory and Practice. The Finnish Journal of Business Economics, 4, 387-403.

Hendrikse, G.W.J., Smit, R., \& de la Vieter, M. (2007). Orientation in Diversification Behavior of Cooperatives: An Agent-Based Approach. Economics and Management of Networks. Contributions to Management Science, 421-435.

Hendrikse, G.W.J., \& Veerman, C.P. (2001). Marketing Co-operatives: An Incomplete Contracting Perspective. Journal of Agricultural Economics, 52, 53-64. http://dx.doi.org/10.1111/j.1477-9552.2001.tb00909.x

Holmstrom, B. (1999). Future of Cooperatives: A Corporate Perspective. The Finnish Journal of Business Economics, 4. 404-417.

Homans, G. C. (1958). Social behavior as exchange. American Journal of Sociology, 62, 597-606. http://dx.doi.org/10.1086/222355

International Co-operative Alliance (2012a). Retrieved April 17, 2012 from the 2012 International Year of Cooperatives facts and figures. [Online] Available: http://www.2012.coop/en/ica/co-operative-facts-figures

International Co-operative Alliance (2012b). Retrieved April 17, 2012 from the Global 300 and Developing 300 database. [Online] Available: http://www.global300.coop.

Johnson, P. (2006). Whence democracy? A Review and Critique of the Conceptual Dimensions and Implications of Business Case for Organizational Democracy. Organization, 13, 245-274. http://dx.doi.org/10.1177/1350508406061676

Jones, D., \& Kalmi, P. (2009). Trust, Inequality and the Size of the Co-operative Sector: Cross-Country Evidence. Annals of Public and Co-operative Economics, 80, 165-195. http://dx.doi.org/10.1111/j.1467-8292.2009.00383.x

Jussila, I., Saksa, J-M., \& Tienari, J. (2007). Dynamics and Tensions in Governance: Evidence from Finnish Co-operatives. International Journal of Co-operative Management, 3, 29-39.

Kaplan de Drimer, A. (1997). Will cooperatives be able to preserve their nature and their members' general interest in the face of structural changes? Annals of Public and Cooperative Economics, 68, 469-483. http://dx.doi.org/10.1111/1467-8292.00059

Katz, J., \& Boland, M. (2002). One for All and All for One? A New Generation of Co-operatives Emerges. Long Range Planning, 35, 73-89. http://dx.doi.org/10.1016/S0024-6301(02)00024-9

Kurimoto, A. (2008). Structure and Governance of Networks: Cases of Franchising and Co-operative Chains. Strategy and Governance of Networks. Contributions to Management Science, 63-82.

Lang, R., \& Roessl, D. (2011). Contextualizing the Governance of Community Co-operatives: Evidence from Austria and Germany. Voluntas, 22, 706-730. http://dx.doi.org/10.1007/s11266-011-9210-8

Lawler, E. J. (2001). An affect theory of social exchange, American Journal of Sociology, 107, 321-352. http://dx.doi.org/10.1086/324071

Lawler, E. J., \& Yoon, J. (1993). Power and the emergence of commitment behavior in negotiated exchange, American Sociological Review, 58, 465-481. http://dx.doi.org/10.2307/2096071

Lawler, E. J., \& Yoon, J. (1996). Commitment in exchange relations: Test of a theory of relational cohesion, American Sociological Review, 61, 89-108. http://dx.doi.org/10.2307/2096408

Lawler, E. J., \& Yoon, J. (1998). Power and the emergence of commitment behavior in negotiated exchange, American Sociological Review, 63, 871-894. http://dx.doi.org/10.2307/2657506 
Lévi-Strauss, C. (1969). The Elementary Structures of Kinship. Boston: Beacon.

Michelsen, J. (1994). The Rationales of Cooperative Organizations. Some Suggestions from Scandinavia. Annals of Public and Cooperative Economics, 65, 13-34. http://dx.doi.org/10.1111/j.1467-8292.1994.tb01504.x

Molm, L. D. (1994). Dependence and Risk: Transforming the Structure of Social Exchange. Social Psychology Quarterly, 57, 163-176. http://dx.doi.org/10.2307/2786874

Münkner, H-H. (1981). Co-operative Principles and Co-operative Law. Institute for Co-operation in Developing Countries, Papers and Reports, 5.

Nilsson, J. (1996). The Nature of Cooperative Values and Principles. Annals of Public and Cooperative Economics, 17, 329-356.

Nilsson, J. (2001). Organizational Principles for Co-operative Firms. Scandinavian Journal of Management, 17, 329-356. http://dx.doi.org/10.1016/S0956-5221(01)00010-0

Normark, P. (1996). A Role for Cooperatives in the Market Economy. Annals of Public and Cooperative Economics, 67, 426-439. http://dx.doi.org/10.1111/j.1467-8292.1996.tb01914.x

Rantanen, N., \& Jussila, I. (2011). F-CPO: A collective psychological ownership approach to capturing realized family influence. Journal of Family Business Strategy, 2, 139-150. http://dx.doi.org/10.1016/j.jfbs.2011.07.005

Rosenblatt, P. C., \& Budd, L. G. (1975). Territoriality and privacy in married and unmarried cohabitating couples. Journal of Social Psychology, 97, 67-76. http://dx.doi.org/10.1080/00224545.1975.9923314

Sahlins, M. (1972). Stone age economics. New York: Aldine.

Saksa, J-M., Jussila, I., \& Tuominen, P. (2007). Producer and Marketing Co-operatives: Institutional Contexts and Strategies. Journal of Co-operative Studies, 40, 5-13.

Sharma, P., Hoy, F., Astrachan, J. H., \& Koiranen, M. (2007). The practice-driven evolution of family business education. Journal of Business Research, 60, 1012-1021. http://dx.doi.org/10.1016/j.jbusres.2006.12.010

Shore, L. M., Tetrick, L. E., \& Barksdale, K. (2001). Social and economic exchanges as mediators of commitment and performance. Unpublished manuscript.

Sousa, J., \& Quarter, J. (2005). Atkinson Housing Co-operative: A Leading Edge Conversion from Public Housing. Housing Studies, 20, 423-439. http://dx.doi.org/10.1080/02673030500062459

Stryjan, Y. (1994). Understanding Cooperatives: The Reproduction Perspective. Annals of Public and Cooperative Economics, 65, 59-79. http://dx.doi.org/10.1111/j.1467-8292.1994.tb01506.x

Spear, R. (2004). Governance in Democratic Member-Based Organizations. Annals of Public and Cooperative Economics, 75, 33-59. http://dx.doi.org/10.1111/j.1467-8292.2004.00242.x

Takala, A. J., Arvonen, V., Katko, T. S., Pietilä, P. E., \& Åkerman, M. W. (2011). The Evolving Role of Water Co-operatives in Finland. International Journal of Co-operative Management, 5, 11-19.

Thibault, J. W., \& Kelley, H. H. (1959). The social psychology of groups. New York: Wiley.

Tuominen, P., \& Jussila, I. (2010). Managerial Competence in Consumer Co-operatives: Inducing Theory from Empirical Observations. International Journal of Co-operative Management, 5, 9-22.

Tuominen, P., Jussila, I., \& Kojonen, S. (2009). Overcoming challenges to governance of consumer co-operation: Analysing reports of key representatives. International Journal of Co-operative Management, 4, 22-35.

Tuominen, P., Jussila, I. \& Saksa, J-M. (2006). Locality and Regionality in Management of Finnish Consumer Co-operatives. International Journal of Co-operative Management, 3, 9-19.

Turnbull, S. (1997). Corporate Governance: Its scope, concerns and theories. Corporate Governance: An International Review, 5, 180-205. http://dx.doi.org/10.1111/1467-8683.00061

Tyler, T. R., \& Blader, S. B. (2001). Identity and cooperative behavior in groups, Group Processes \& Intergroup Relations, 4, 207-226. http://dx.doi.org/10.1177/1368430201004003003

Wilson, E. J., Plummer, J,. Fischlein, M., \& Smith, T.M. (2008). Implementing energy efficiency: Challenges and opportunities for rural electric co-operatives and small municipal utilities. Energy policy, 36, 3383-3397. http://dx.doi.org/10.1016/j.enpol.2008.05.007

Viggiani, F.A. (1999). 'Doing the right thing': Organizational Structure and process for democratic governance in the firm. Industrial Relations Journal, 30, 229-242. http://dx.doi.org/10.1111/1468-2338.00122 